\title{
Environmental management performance and the role of human resources management: Empiri- cal study in quaternary economic sector
}

\author{
Indrayani ${ }^{*}$ and Didi Wahyudi ${ }^{a}$
}

${ }^{a}$ Universitas Batam, Kepulauan Riau, Indonesia

\begin{tabular}{l}
\hline C H R O N I C L E \\
\hline Article history: \\
Received: May 30, 2020 \\
Received in revised format: \\
May 302020 \\
Accepted: July 9, 2020 \\
Available online: \\
July 9, 2020 \\
\hline Keywords: \\
Work ability \\
Leadership \\
Compensation \\
Motivation \\
Performance \\
Environmental management \\
Hospitality industry
\end{tabular}

\section{Introduction}

The establishment of hotels, especially small ones, has increased dramatically in the decade of the 20th century. For comparison, the assessment system has been introduced to one to five stars and also the level of budget hotels in Indonesia. The criteria of hotel business standards are based on Annex I of the Indonesian Minister of Tourism and Creative Economy Regulation Number PM.53/HM.001/MPEK/2013 concerning Hotel Business Standards, one of which is Waste Management. This regulation distinguishes criteria for hotel types and their responsibilities in Waste Management. For non-star hotels, the absolute criteria for environmental management standards that are charged are having waste water management in the form of a septic tank, or similar. Whereas, for starred hotels, the absolute criteria for environmental management standards that are charged are to own the wastewater treatment plant. Starred hotels are one business and/or activity that provides room service, a restaurant equipped with a kitchen, to improve the performance of environmental control, organizations or institutions must harmonize organizational goals with the personal goals of each employee. Every organization should understand the needs of each employee so that employees feel comfortable and satisfied at work (Dobre, 2013). Besides having to understand so that * Corresponding author.

E-mail address: indrayani.uniba@yahoo.com (Indrayani)
The quaternary business sector growth, as an up-to-date form of service, has long been considered and environment, and is separated from the industrial and manufacturing sectors which business is generally considered to have intangible and experience-based services that are considered not to have real consequences on the environment. This study seeks to examine the role of environmental staff in efforts to manage hotels in Batam Indonesia. Furthermore, the study seeks business in Batam. Some key aspects of the HR study, such as compensation and leadership, were nironmental management staff. Analysis of research data is based on path analysis through Strucinfluence between work ability, leadership, and compensation on motivation of environmental staff. Subsequent results show an indirect effect of work skills, leadership, and compensation on performance through motivational mediation variables. The originality of this study lies on its efforts to emphasize that the hospitality business should also be considered a business that has an effect on environmental performance in the implementation of environmentally friendly businesses. The study underscores the importance of standardized environmental management in starred hotel management. In addition, the study offers originality that various forms of appreciation and increased motivation affect not only on improving business performance, but also on environmental performance in managing hospitality services. tested in this study. The method used is a quantitative approach with a sample of 150 respondents 
an organization becomes maximal, every employee must have the ability to work (Schuler, 1977). A person's work ability is an embodiment of the knowledge and skills possessed. Therefore, employees who have high capabilities can support the achievement of the organization's vision and mission to immediately advance and develop. The ability that someone has will make it different from those who have average abilities. Factors that stimulate hotel employees, especially the environmental management staff to achieve their maximum abilities must be encouraged by leadership. A leader must give an example to his subordinates. The leadership factor, can provide guidance to employees in the face of tasks and work environment (Jung et al., 2003). A good leader will be able to transmit his optimism and knowledge so that employees who are subordinates can carry out the work properly. Besides that, in carrying out work, environmental management staff cannot be separated from compensation from the results of the achievements that have been achieved (Suharno et al., 2016). Furthermore, the performance of environmental management staff in starred hotels in Batam City is reflected in the level of fulfillment of the quality standards of wastewater treatment plants (WWTPs) that are met and permits obtained by star hotels in Batam City, such as the number of starred hotels not equipped with WWTPs and if there are test results. laboratory against waste water has not met the required quality standards. All of that can hamper performance for star hotel management. Factually, based on data obtained from the Batam City Environmental Agency, the number of star hotels currently in Batam City is 83 . Of these, only 5 hotels have permits to dispose of waste water. This means that only six percent have fulfilled water pollution control performance well. This can be reviewed with the unavailability of wastewater treatment plant and environmental management facilities with highly capable staff at each star hotel. More specifically, the identification of problems in this study includes the lack of star hotels in Batam City which have a wastewater treatment plant, limited work ability of environmental management staff in operationalizing the wastewater treatment plant, commitment of leadership of star hotels that tend to lack environmental management. Some literature in environmental studies have also highlighted this relationship of human resource and environmental performance (Alkhateeb et al, 2018; Nik.zadian et al., 2019). In addition, in the organizational relations of the company's human resources, the form of compensation was felt to be lacking given to environmental management staff in efforts to manage the environment, lack of motivation from the managers of star hotels in Batam in providing and operating the wastewater treatment plant, and environmental management staff performance has not been achieved in an effort to control the environment. In this context, this study seeks to analyze several variables that determine environmental management performance in star hotels in Batam City, namely work ability (X1), leadership (X2), compensation (X3), motivation (Y), and performance $(Z)$. The reason for this study is due to the need for empirical data on variables that have an effect on environmental management staff in achieving good performance, and research has never been conducted on environmental management in several star hotels in Batam City, Indonesia.

\section{Literature Review and Hypotheses}

\subsection{Hospitality Performance in the Environmental Management Perspective}

The criteria for the performance of starred hotels in environmental control based on the Regulation in Law Number 32 of 2009 concerning Environmental Protection and Management stipulates that the performance of waste water management is by fulfilling quality standards and obtaining permits. This is as written in Article 20 Paragraph (3) of the regulation which states that everyone is permitted to dispose of waste into environmental media with the following requirements: meeting environmental quality standards; and get permission from the minister, governor, or regent/mayor in accordance with their authority. From the dimensions that have been proposed by Robbins and Judge (2006) a person's ability can be seen from the knowledge and skills possessed supported by his physical and intellectual condition. Thus, in carrying out a job, it is not enough if only have knowledge and skills, but must be supported by a strong ability to carry out the work. Indicators that influence ability are knowledge, skills, physical, and intellectual (Carneiro, 2000). Knowledge is information that has been processed and organized to gain understanding, learning and accumulated experience so that it can be applied to the work of the employee itself (Brown \& Duguid, 1991). Skills are the ability of employees to complete work effectively and efficiently in a particular technical implementation of work related to individual tasks in an organization (Bowen et al., 1991). Special abilities that have important meaning to do jobs that are less demanding skills and are more standardized successfully. For example, work whose success requires a good stamina, hand dexterity, and leg strength, or similar talent requires management to recognize the physical capabilities of an employee. Intellectual is the ability needed to carry out mental activities (Mulder, 1986). The seven most frequently cited dimensions that give intellectual ability are numerical skills, verbal comprehension, perceptual speed, inductive reasoning, deductive reasoning, space and memory visualization.

\subsection{Work ability, Motivation and Performance}

The aspects assessed in performance are divided into several perspectives. The aspect of cooperation is an assessment of the willingness of employees to participate and cooperate with employees vertically and horizontally inside and outside the work so that the results of their work will be better (Burgess, 2005). Aspects of responsibility and skills related to the assessment of the willingness of employees to account for their policies, work and results, facilities and infrastructure used, and work behavior (Kalleberg, 2009). Discipline aspect is an evaluation of employee discipline in complying with existing regulations and doing their work in accordance with the instructions given to them. Regarding attitude, it is an assessment of employees from behavioral attitudes, politeness, cheerful likes, giving pleasant impressions, paying attention to good attitudes, and sympathetic and reasonable appearance. 
The next aspect is creativity. This ability involves evaluating the ability of employees to develop their creativity to complete their work, so that they work more efficiently and effectively (Oldham \& Cummings, 1996). Another personal aspect is honesty, which is an assessment of honesty in carrying out its duties to fulfill agreements both for themselves and for others as with their subordinates (Santra, 2018). Initiative is an assessment of original thinking skills and based on its own initiative to analyze, give reasons, get conclusions, and make decisions to resolve the problems it faces. Reliability is an assessment of the work results of both the quality and quantity that the employee can produce from the job description (Hogan \& Hogan, 1989). Loyalty is an assessment in measuring employee loyalty to his job, position, and organization. This loyalty is reflected in the willingness of employees to protect and defend organizations both inside and outside of work from undermining irresponsible people (Matzler \& Renzl, 2006). Finally, leadership is an assessment of the ability to lead, influence, have a strong, respected, authoritative person, and can motivate other people or subordinates to work determinatively. Based on these descriptions, these relationships are also considered to be reflected in environmental management in star hotels, where work abilities are considered to be the influence of the employee motivation (Kehr, 2004), and work abilities can influence the job performance (Schmidt \& Hunter, 2004). Thus, the following hypotheses were proposed in this study

$\mathbf{H}_{1}$. Work ability influences the motivation of environmental management staff in starred hotels.

H2. Work ability influences the performance of the environmental management staff in starred hotels.

\subsection{Leadership, Motivation and Performance}

According to Wibowo (2010), leadership model would listen attentively to the input of subordinates and specifically want to pay attention to the needs of subordinates of career development. The leader behavior framework generally includes aspects such as tolerance, justice and empowerment. According to Swietenia (2009) leaders can build trust, involvement, and collaboration between team members. Leaders must place high trust in employees (Mayfield \& Mayfield, 2002). This means that without hesitation to employees with one belief the task will be carried out properly. Giving trust by itself will instill and increase the confidence of employees. Other aspects are related to giving rewards and participation to subordinates. The democratic aspect is openness and desire to position work from, by, and to be together. Democratic leadership is a leadership style where leaders play a permissive role. The term permissive means to allow. Furthermore, democratic leadership is leadership based on the assumption that only because of dynamic group interaction, organizational goals can be achieved. With dynamic interactions, it is intended that leaders delegate tasks and give trust to those they lead to achieve quality goals quantitatively. The participatory aspect means involving subordinates in decision making (Scandura et al., 1986). The leader asks for comments, opinions, and suggestions from the employees on what will be done. Thus, the employees feel partially responsible for the decisions taken by the leader. The aspect of appreciation, is something that is expected to be obtained called an award or reward (Ariyanti et al., 2018). Broadly speaking, awards can be divided into two, namely: intrinsic rewards and extrinsic rewards. Sehfudin and Mas'ud (2011) believe intrinsic appreciation is something that is felt by himself when doing something. Something that is felt can be in the form of satisfaction in doing the task, feeling relieved because it has completed the task this has an impact on an increase in self-confidence. While extrinsic award is something that is accepted by someone from the environment where he works where something he gets is in accordance with his expectations, such with promotion.

$\mathbf{H}_{3}$. Leadership influences the motivation of environmental management staff in starred hotels.

H4. Leadership influences the performance of the environmental management staff in starred hotels.

\subsection{Compensation, Motivation and Performance}

According to Rivai and Jauvani (2010), compensation is something that employees receive as a substitute for their service contribution to the company. Giving compensation is one of the functions of Human Resource Management (HRM) that deals with all types of individual awards in exchange for carrying out organizational tasks. The type of compensation as an indicator is divided into 2. First, financial compensation is divided into 2 types, namely direct and indirect compensation. Direct compensation consists of employee payments in the form of wages, salaries, bonuses or commissions, whereas indirect compensation consists of all payments not covered by direct financial compensation which includes vacation, insurance, care and religious care. Second, non-financial compensation. Non-financial compensation can include praise, self-respect, and recognition that can affect employee work motivation, productivity and satisfaction. According to Baldoni (2005), motivation is an active process that is driven by a series of actions that can be grouped into several aspects. First, energizing as empowering efforts, is what leaders do when they give examples, communicating clearly, and providing challenges correctly. Second, encouraging is what leaders do to support the motivational process through empowerment, coaching, and recognition. Third, exhort is how leaders create experiences based on sacrifice and inspiration that prepare the basis for motivation to be able to thrive.

H5. Compensation has an effect on motivation on environmental management staff in starred hotels.

H6. Compensation has an effect on the performance of environmental management staff in starred hotels. 


\subsection{Motivation and Performance}

Motivation is a set of attitudes and values that influence individuals to achieve specific things in accordance with individual goals, besides that it can be interpreted as encouraging individuals to take action to create a pleasant work climate (Lindner, 1998). With this motivation, it affects the ability of work. The motivation to create a pleasant work climate, and the existence of leaders who always inspire and always create an urge to create employees. This is done by leaders so that employees can work beyond their limits and be motivated, and valued. The form of award is given in the form of compensation. Compensation stimulates an employee himself and creates competitiveness. Besides the leader wants to get the optimal work results of the employee and achieve the target with motivation, also the opportunity employees get an award from the office. Through this, employees will have their own personal targets and achieve their job performance (Barrick et al., 2002).

H7. Motivation affects the performance of the environmental management staff in starred hotels.

H8. Motivation is able to strengthen the effect of work ability, leadership and compensation on performance on the environmental management staff in starred hotels.

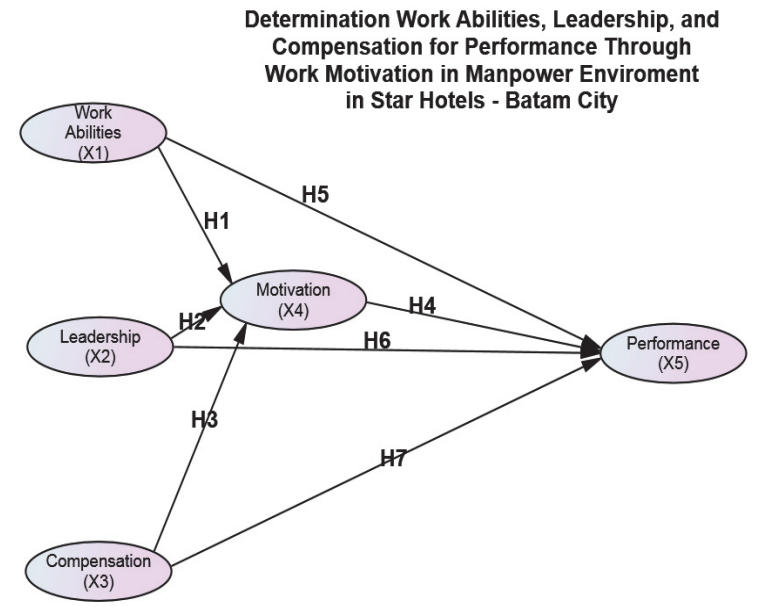

Fig. 1. Research Framework with SEM Analysis Model

\section{Research methods}

The population is star-rated hotel employees in Koyang, registered at the Department of Environment and Employees of the Batam City Environmental Agency as many as 239 people. The researcher took the sampling technique focusing on the purposive sampling technique. According to Sugiyono (2012), Purposive sampling is a technique of determining samples with certain considerations. In addition, according to Arikunto (2010), Purposive sampling is done by taking a subject not on strata, random or regional but based on the existence of certain objectives. This technique is usually done because of several considerations, for example the reason for the limitations of time, energy, and funds so that they do not take large and far samples. Based on Ridwan and Akdon (2009), how to calculate samples using Slovin formula is as $n=\left(\frac{\mathrm{N}}{1+\left(\mathrm{N} \cdot d^{2}\right)}\right)$,

where $\mathrm{n}=$ number of samples; $\mathrm{d}=$ error limit used $5 \% ; \mathrm{N}=$ Sample size

The total population in this study were environmental management employees at star-rated hotels registered with the Batam City Environmental Agency as many as 239 employees.

$n=\left(\frac{\mathrm{N}}{1+\left(\mathrm{N} \cdot d^{2}\right)}\right)=\left(\frac{239}{1+\left(239 \cdot 0 \cdot 05^{2}\right)}\right) \approx 150$

The technique of collecting data to obtain primary data is done by giving a questionnaire to environmental management staff regarding work ability, leadership, compensation, and to leaders or managers regarding motivation in Star Hotels - Batam City. The scale used in the measurement scale of research instruments on work ability (X1), leadership (X2), compensation (X3), and motivation (y) and performance $(\mathrm{Z})$ is using the Likert scale from 1 (strongly disagree) to 5 (strongly agree). The data analysis technique in this study uses path analysis. The regression equation is: 


\section{Results}

\subsection{The profiles of respondents}

Most respondents were in the productive age range of $35-45$ years as many as 75 people or $50 \%$, followed by respondents with an age range of 25-35 years as many as 60 people or $40 \%$. From the aspect of education, most of the respondents were high school graduates as many as 105 people $(70 \%)$, followed by respondents graduating from the diploma program as many as 28 people $(19 \%)$, and undergraduates as many as 17 people $(11 \%)$. In terms of experience, the majority of respondents have worked more than 3 years as many as 83 people (55\%). For WWTP ownership, the comparison between the number of hotels with WWTP ownership and those that do not is 72 compared to 78 with no WWTP or 52\%: $48 \%$.

Table 1

Respondent Profiles and Facilities of the Wastewater Treatment Plant

\begin{tabular}{cccccccccc}
\hline & Age & & \multicolumn{3}{c}{ Education } & \multicolumn{2}{c}{ Experience } & \multicolumn{2}{c}{ WWTP ownership } \\
\hline $25-35$ & $36-45$ & $46-55$ & Highschool & Diploma & Undergraduate & $<3$ years & $>3$ years & yes & No \\
\hline 60 & 75 & 15 & 105 & 28 & 17 & 67 & 83 & 72 & 78 \\
$40 \%$ & $50 \%$ & $10 \%$ & $70 \%$ & $19 \%$ & $11 \%$ & $45 \%$ & $55 \%$ & $48 \%$ & $52 \%$ \\
\hline
\end{tabular}

\subsection{Evaluation of Goodness of Fit}

In accordance with the purpose of the study to find out and explain the Ability of Work, Leadership, Compensation, Motivation, and Performance. Performance as determination through Motivation in Environmental Management Staff In starred hotels coupled with hypotheses that have been formulated, the data analysis is done using the Structural Equation Modeling (SEM) which is a statistical engineering analysis that allows testing of a series of relative relationships. simultaneously (Ferdinand, in Adi, 2008: 55).

Table 2

Evaluation of Modified Goodness of Fit (Model Revision)

\begin{tabular}{ccccc}
\hline Index & Cut-off-value & Results & & Verification \\
\hline Chi-square $\left(\mathrm{X}^{2}\right)$ & Small & 283.473 & & \\
Relative chi-square $\left(\mathrm{X}^{2} / \mathrm{df}\right)$ & $\leq 3.00$ & 1.143 & Very good \\
Probability & $>0.05$ & 0.060 & Very good & Good \\
RMSEA & $\leq 0.08$ & 0.031 & Very good \\
GFI & $\geq 0.90$ & 0.879 & Good & Good \\
AGFI & $\geq 0.90$ & 0.842 & Very good \\
TLI & $\geq 0.94$ & 0.948 & Very good \\
CFI & $>0.94$ & 0.957 & \\
\hline
\end{tabular}

From Table 2, it can be seen that the overall model shows a good level of conformity. Thus, it can be said that the results of testing the goodness of fit on the standard model used in this study indicate that the observed data is appropriate or consistent with the theory or model to be tested. Although AGFI is considered good but can still meet the requirements, so the proposed model is considered very good and can be accepted as an appropriate model in this study.

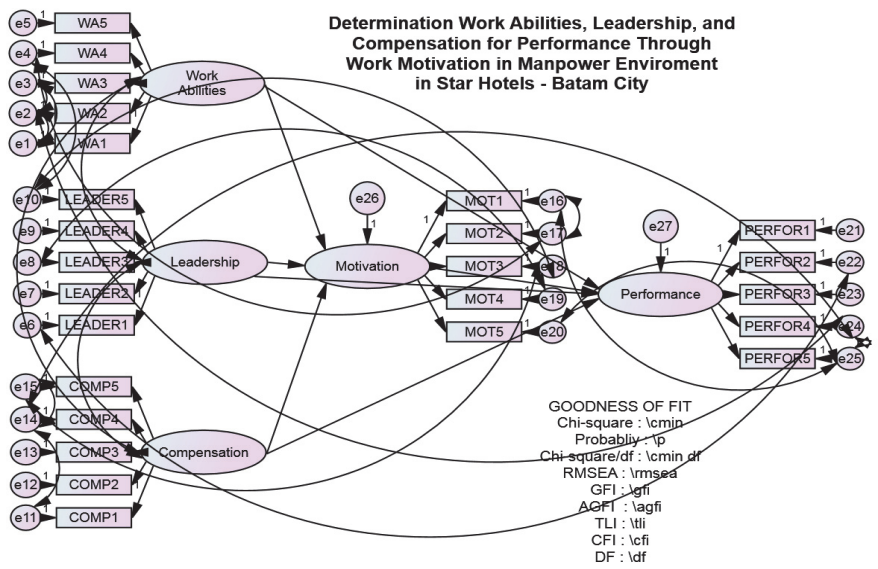

Fig. 2. Comprehensive SEM model (after modifying the index) 


\subsection{Regression Weights}

Further analysis of regression weights requires that if the standardized estimate (regression weight) $>0.50$, the value of CR $>$ $\mathrm{t}$-table $=1.96$, and probability $(\mathrm{P})<0.05$, then the parameter loading factor $(\lambda)$ is stated significant (Ferdinand, 2008: 225). This means, the indicator is valid. For the purposes of testing the parameters $(\lambda)$, the following table is shown which contains loading factors $(\lambda)$, C.R, probability $(\mathrm{P})$.

Table 3

Regression Weights

\begin{tabular}{|c|c|c|c|c|}
\hline Hypotheses & Estimate & S.E & C.R & p \\
\hline MOT $\leftarrow$ WORK & .635 & .120 & 2.657 & .021 \\
\hline MOT <COMP & .746 & .136 & 3.273 & .001 \\
\hline MOT $\leftarrow$ LDR & .595 & .079 & 2.334 & .035 \\
\hline $\mathrm{PERF} \leftarrow \mathrm{MOT}$ & .620 & .096 & 2.419 & .025 \\
\hline $\mathrm{PERF} \leftarrow \mathrm{LDR}$ & .782 & .168 & 2.555 & .019 \\
\hline $\mathrm{PERF} \leftarrow$ WORK & .954 & .318 & 3.609 & .002 \\
\hline $\mathrm{PERF} \leftarrow \mathrm{COMP}$ & .853 & .296 & 2.881 & .004 \\
\hline
\end{tabular}

Note: $\mathrm{MOT}=$ motivation; WORK= work ability; COMP: compensation; LDR=leadership; PERF=performance

From Tables 3, it can be seen that all indicators of latent variables have standardized estimate (regression weight) in the form of loading factor or $\lambda>0.50$, critical value CR $>1.96$ and have probabilities smaller than 0,05 . Thus, it can be said that all indicators of the latent variable are valid or significant.

Table 4

Recapitulation of direct effect and indirect effect parameter values

\begin{tabular}{|c|c|c|c|c|c|c|}
\hline \multirow[t]{2}{*}{ Hypotheses } & \multicolumn{3}{|c|}{ Direct Effect } & \multicolumn{3}{|c|}{ Indirect effect } \\
\hline & $\begin{array}{c}\text { Standardized Es- } \\
\text { timate }\end{array}$ & C.R & $p$ & $\begin{array}{c}\text { Standardized Es- } \\
\text { timate }\end{array}$ & C.R & $p$ \\
\hline MOT $\leftarrow$ WORK & .635 & 2.657 & .021 & & & \\
\hline $\mathrm{MOT} \leftarrow \mathrm{COMP}$ & .746 & 3.273 & .001 & & & \\
\hline MOT $\leftarrow$ LDR & .595 & 2.334 & .035 & & & \\
\hline $\mathrm{PERF} \leftarrow \mathrm{MOT}$ & .620 & 2.419 & .025 & & & \\
\hline $\mathrm{PERF} \leftarrow \mathrm{LDR}$ & .782 & 2.555 & .019 & 0.056 & 2.555 & .019 \\
\hline $\mathrm{PERF} \leftarrow \mathrm{WORK}$ & .954 & 3.609 & .002 & 0.020 & 3.609 & .002 \\
\hline $\mathrm{PERF} \leftarrow \mathrm{COMP}$ & .853 & 2.881 & .004 & 0.007 & 2.881 & .004 \\
\hline
\end{tabular}

In the hypothesis 1 test, there is a positive and significant effect of work ability on motivation, providing information is acceptable, because the CR value of the relationship between the two variables is 2.657 with a $p$ value of 0.021 , so that it is considered fulfilling the requirements which are still above 1.96 for CR and below 0.05 for $p$ value. In addition, both of these variables have direct effect of 0.635 . Leaders are unable to inspire what their subordinates expect so that there is no motivation, and leaders lack democracy towards their subordinates. Further analysis show that there is a positive and significant effect of work ability on performance, providing information is acceptable, because the CR value of the relationship between the two variables is 3.609 with a $p$ value of 0.002 , so that it is considered to be qualified above 1.96 for CR and below 0.05 for the $p$ value, it can be seen that the $\mathrm{P}$ and $\mathrm{CR}$ values meet the requirements. Both of these variables have a direct effect of 0.954 . Besides that, there is an indirect effect of 0.040 which reflects an indirect influence. The ability to work that is not in their field or according to their expertise, will decrease the performance of environmental management staff. This is caused by difficulty in adapting and of understanding work. Work ability will be reduced due to lack of knowledge so that skills have a negative impact on performance. Thus, it is better for someone who is truly capable in his field.

In the hypothesis 3 test, there is a positive and significant effect of leadership on motivation, providing information is acceptable, because the CR value of the relationship between the two variables is 2,334 with a $p$ value of 0,035 . Besides that, both of these variables have a direct effect of 0.595 . Thus, that the development in the leader, the initiative to reward environmental management staff will be able to provide positive motivation. The leader can inspire from what is expected by his subordinates so that motivation appears, and especially for leaders who are democratic towards their subordinates. The statistical testing of the hypothesis 7 shows that there is a positive and significant effect of leadership on performance, providing information is acceptable, because the CR value of the relationship between the two variables is 2.555 with a $p$ value of 0.019 , which is considered to be above 1.96 for CR and in under 0.05 for the $p$ value. Both of these variables have a direct effect of 0.782 . Besides that, there is an indirect effect of 0.011 which reflects an indirect influence. From leadership, it can be seen that it can have a significant effect on performance. This is due to several factors, including that leaders must be able to provide good, or inspiring examples, so that the performance of environmental management staff is better. 
In the hypothesis 5 test, there is a positive and significant effect of compensation on motivation, providing information can be received, because the value of the CR relationship between the two variables is 3.273 with a $p$ value of 0.001 . In addition, both of these variables have a direct effect of 0.746 . Compensation went well and environmental management staff needs were fulfilled so that it began to increase motivation within environmental management staff. In addition, creating healthy competition so that employees who excel and get greater awards will motivate environmental management staff. In the hypothesis 6 test, there is a positive and significant effect of compensation on performance, providing information is acceptable, because the CR value of the relationship between the two variables is 2.881 with a $p$ value of 0.004 . Both of these variables have a direct effect of 0.853 . Besides that, there is an indirect effect of 0.053 which reflects an indirect influence. It can be seen from the significance that the compensation for environmental management staff has an impact on better performance. This will cause environmental management staff to have original thinking skills and own initiatives to analyze, give reasons, get conclusions, and make decisions to resolve the problems it faces.

In the hypothesis 7 test, there is a positive and significant influence on motivation on performance, providing information is acceptable, because the CR value of the relationship between the two variables is 2.419 with a $p$ value of 0.025 . Besides that, both of these variables have a dirrect effect of 0.620 . From motivation, it can be seen that it can significantly affect performance. This is due to several factors, including: employees like to work, are responsible for work, and cooperate between good employees. In the hypothesis 8 test, the formulation produced from the standard regression weight is:

$$
\begin{aligned}
& Y=0.547 X_{1}+0.500 X_{2}+0.632 X_{3} \\
& Z=0.818 X_{1}+0.642 X_{2}+0.628 X_{3}
\end{aligned}
$$

While the results of the coefficient determination appear to be the magnitude of the effect together on motivation (Y) is $63.8 \%$, which is based on the contribution of three variables namely work ability, leadership and compensation, while performance $(Z)$ is $71 \%$, based on the contribution of 3 variables namely motivation, work ability, and compensation.

\section{Conclusion}

This study aims to analyze with SEM on a number of independent variables of work ability, leadership, compensation, on the performance, through the mediating effect of motivation in starred hotel taking the object of environmental assessment criteria. The findings show that performance was influenced by ability to work, leadership, compensation, motivation. From the overall data analysis can be concluded all indicators for ability to work, leadership, compensation, motivation and performance are valid or significant. In this context, the hotel leader should provide a policy on environmental management that can increase the motivation of environmental management staff in working by providing the wastewater treatment plant and adequate funding for its operations. To the City Environment Agency, it is encouraged to routinely carry out supervision as an effort to push so that the motivation of the environmental management staff and the policies of the hotel leaders will increase.

\section{References}

Alkhateeb, T.T.Y., \& Alkahtani, N.S., \& Mahmood, H. (2018). Green Human Resource Management, Financial Markets and Pollution Nexus in Saudi Arabia. International Journal of Energy Economics and Policy 8(3), 33-36.

Arikunto, S. (2010). Prosedur penelitian: Suatu Pendekatan Praktik. Jakarta : Rineka Cipta

Ariyanti, N. K. I., Santra, I. K., \& Lasmini, N. K. (2018). Leadership and organizational culture analysis on organizational citizenship behavior (OCB) at PT. Hatten Bali. Jurnal Riset Bisnis dan Investasi, 3(3), 33-44.

Baldoni, J. (2005). Great Motivation Secrets of Great Leaders (POD). McGraw Hill Professional.

Barrick, M. R., Stewart, G. L., \& Piotrowski, M. (2002). Personality and job performance: Test of the mediating effects of motivation among sales representatives. Journal of Applied Psychology, 87(1), 43.

Bowen, D. E., Ledford Jr, G. E., \& Nathan, B. R. (1991). Hiring for the organization, not the job. Academy of Management Perspectives, 5(4), 35-51.

Brown, J. S., \& Duguid, P. (1991). Organizational learning and communities-of-practice: Toward a unified view of working, learning, and innovation. Organization Science, 2(1), 40-57.

Burgess, D. (2005). What motivates employees to transfer knowledge outside their work unit?. The Journal of Business Communication (1973), 42(4), 324-348.

Carneiro, A. (2000). How does knowledge management influence innovation and competitiveness?. Journal of Knowledge Management, 4(2), 87-98.

Dobre, O. I. (2013). Employee motivation and organizational performance. Review of Applied Socio-Economic Research, 5(1).

Hogan, J., \& Hogan, R. (1989). How to measure employee reliability. Journal of Applied Psychology, 74(2), 273.

Jung, D. I., Chow, C., \& Wu, A. (2003). The role of transformational leadership in enhancing organizational innovation: Hypotheses and some preliminary findings. The Leadership Quarterly, 14(4-5), 525-544.

Kalleberg, A. L. (2009). Precarious work, insecure workers: Employment relations in transition. American Sociological Review, 74(1), 1-22. 
Kehr, H. M. (2004). Integrating implicit motives, explicit motives, and perceived abilities: The compensatory model of work motivation and volition. Academy of Management Review, 29(3), 479-499.

Lindner, J. R. (1998). Understanding employee motivation. Journal of Extension, 36(3), 1-8.

Matzler, K., \& Renzl, B. (2006). The relationship between interpersonal trust, employee satisfaction, and employee loyalty. Total Quality Management and Business Excellence, 17(10), 1261-1271.

Mayfield, J., \& Mayfield, M. (2002). Leader communication strategies critical paths to improving employee commitment. American Business Review, 20(2), 89-94.

Mulder, G. (1986). The concept and measurement of mental effort. In Energetics and Human Information Processing (pp. 175-198). Springer, Dordrecht.

Nikzadian, A., Agheli, L., Arani, A. A., \& Sadeghi, H. (2019). The Effects of Resource Rent, Human Capital and Government Effectiveness on Government Health Expenditure in Organization of the Petroleum Exporting Countries. International Journal of Energy Economics and Policy, 9(2), 381-389.

Oldham, G. R., \& Cummings, A. (1996). Employee creativity: Personal and contextual factors at work. Academy of Management Journal, 39(3), 607-634.

Ridwan., \& Akdon, S. (2009). Aplikasi statistika dan metode penelitian untuk administrasi dan manajemen. Bandung: Dewa Ruchi.

Rivai, V., \& Jauvani, S. (2010). Manajemen Sumber Daya Manusia Untuk Perusahaan Jakarta: Rajawali Pers.

Robbins, S. P., \& Judge, T. A. (2006). Perilaku organisasi. Jakarta: PT Indeks Kelompok Gramedia.

Santra, I. K. (2018). Entrepreneurial orientation and marketing performance of budget hotel SMEs in Bali Island. International Journal of Entrepreneurship, 22(4), 1-11.

Scandura, T. A., Graen, G. B., \& Novak, M. A. (1986). When managers decide not to decide autocratically: An investigation of leader-member exchange and decision influence. Journal of Applied Psychology, 71(4), 579.

Schmidt, F. L., \& Hunter, J. (2004). General mental ability in the world of work: occupational attainment and job performance. Journal of Personality and Social Psychology, 86(1), 162.

Schuler, R. S. (1977). The effects of role perceptions on employee satisfaction and performance moderated by employee ability. Organizational Behavior and Human Performance, 18(1), 98-107.

Sehfudin, A., \& Mas'ud, F. (2011). Pengaruh Gaya Kepemimpinan, Komunikasi Organisasi Dan Motivasi Kerja Terhadap Kinerja Karyawan (Studi Pada PT Bank Tabungan Pensiunan Nasional Cabang Semarang) (Doctoral dissertation, Universitas Diponegoro).

Sugiyono. (2012). Metode Penelitian Kuantitatif Kualitatif dan R\&B. Bandung: Alfabeta.

Suharno, Susilowati, I., Anggoro, S., Gunanto, E.Y.A. (2016). The fisheries management for small-scaler of shrimp fishers in cilacap using bionomics model. International Journal of Applied Business and Economic Research 14(10), pp. 69156920

Swietenia, R. (2009). Analisis Pengaruh Kepemimpinan, Kompensasi dan Karakteristik Pekerjaan Terhadap Disiplin Kerja Serta Implikasinya Terhadap Kinerja Pegawai (Studi Pada Kantor Pertanahan Kota Semarang). Jurnal Ekonomi-Manajemen-Akuntansi, (26), 96-116.

Wibowo. (2010). Manajemen Kerja. Jakarta: Rajawali Pers.

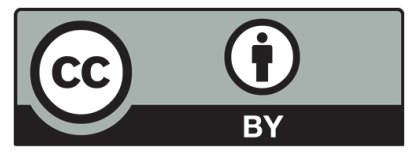

(C) 2020 by the authors; licensee Growing Science, Canada. This is an open access article distributed under the terms and conditions of the Creative Commons Attribution (CC-BY) license (http://creativecommons.org/licenses/by/4.0/). 